\title{
Influence of Learning Model Type Cooperative Scramble with Picture Media on Motivation and Student's Learning Outcomes of IPS Class 2 SDN 2 Tropodo
}

\author{
Atik Artiningsih ${ }^{1, a^{*}}$, Yatim Riyanto ${ }^{1, b}, \&$ Harmanto ${ }^{1, c}$ \\ ${ }_{1}^{1}$ Postgraduate of Basic Education, Surabaya State University, East Java, 60213, Indonesia \\ Jl. Rektorat Unesa, Lidah Wetan Kecamatan Lakarsantri Surabaya, East Java, 60213, Indonesia \\ Email: a atikningsih78@gmail.com, b jatimriyanto@gmail.com, c harmanto@unesa.ac.id \\ ${ }^{*}$ Corresponding Author \\ Whatsapp Number $\{+62-85785402451\}$
}

How to Cite : Artiningsih, A.,Riyanto, Y., \& Hermanto. (2019). Influence of Learning Model Type Cooperative Scramble with Picture Media on Motivation and Student's Learning Outcomes of IPS Class 2 SDN 2 Tropodo. International Journal for Educational and Vocational Studies, 1 (2), 81-85.

\section{ARTICLE HISTORY}

Received: 5 May 2019

Revised: 22 May2019

Accepted: 28 June 2019

\section{KEYWORDS}

Cooperative Scramble;

Motivation;

Picture Media;

Student's Learning Outcomes;

\begin{abstract}
This study aims to determine the effect of the Scramble type cooperative learning model with image media on the motivation and learning outcomes of grade 2 elementary school students. This research was conducted at the SDN Tropodo 2 Waru Sidoarjo Regency 2018/2019. This type of research experiment uses a quantitative approach, with nonequivalent (pretest and posstest) design contril group design. This study uses two classes namely the experimental class and the control class. The study sample was class $2 \mathrm{~A}$ as the experimental class and $2 \mathrm{~B}$ as the control class. The instruments used were motivation observation sheets and learning outcomes tests. Data analysis techniques used included normality test, homogeneity test, and independent sample t-test. The results of the study showed that there was an effect oflearning model the scramble type cooperative on media images on the motivation and learning outcomes of grade 2 elementary school students.value of gain normalized Motivatedexperiment class 0.174 , control class 0.115 value gain normalized of student learning outcomes experimental class 0.192 , control class 0.141 test results independent samples t-test motivation showed tcount of $7.845>$ ttable of 1,677 . the results of the test of independent samples t-test of learning outcomes indicate that the value of tcount is $5.254>$ ttable of 1,677 . It can be concluded that thelearning model scramble type cooperative with image media influences the motivation and learning outcomes of grade 2 students in elementary school.
\end{abstract}

This is an open access article under the CC-BY-SA license.

\section{INTRODUCTION}

Education is an effort to prepare students to be active and positive in their present and future lives. In Indonesia the application of education refers to the national education system (Sisdiknas) 20 of 2013 which is an integrated whole of all educational units and activities that are interrelated to seek the achievement of national education goals. The course of education held in schools is formally preceded by basic education which is a formal education, until tertiary education cannot avoid learning activities because it is the main activity with the teacher as the main role holder in learning. In the educational environment can not be separated from learning activities, the main and main activities are activities that direct the development of student behavior (Hidayah, 2004: 13).learning activities Sc- hooldirect students to be able to accept and understand knowledge gained from teacher explanations in learning activities. The process of changing behavior and one's changes is obtained through education, through training and learning efforts sought to mature people. the quality of education must continue to be improved. Developing countries all over the world try to improve the quality of education which is a central issue including Indonesia. The government seeks the quality of education in various ways such as: curriculum change, teacher upgrading, improved educational facilities and infrastructure, but in reality the government's efforts have not achieved maximum results. Therefore, to improve human resources (HR) education is a very important tool, in ensuring the sustainability of a nation's development (Tirtarahardja and Sulo, 2008: 263). 
According to RI Law No. 2 of 1989 concerning National Education System explained that the level of basic education is education held to provide basic provisions needed to live in society in the form of knowledge, development of attitudes, and basic skills (Tirtarahardja and Sulo, 2008: 265). Basic Education according to RI Law No.20 of 2003 Article 17 paragraph 1 and 2 constitutes basic education discussed is specifically for elementary education. The purpose of elementary education is intended as a process of developing the most basic abilities of each student. Every student actively learns because there is an encouragement in themselves and an atmosphere that provides convenience (conducive) for optimal development of themselves (Mirasa quoted Susanto, 2013: 70).

Based on the observations of researchers on students in grade $2 \mathrm{~A}$ and $2 \mathrm{~B}$ the first problem encountered was during social studies learning, there were still many less motivated students who were still less active and still looked less interactive. These problems are seen when the learning process is in progress. Students are only fixated on textbooks, less interesting learning, and there are students who are free from teacher observation so that students are only busy with their own workPostgraduate Thesis Social Sciences Education Faculty of Teacher Training and EducationUniversity Lampungin 2014 stated that in social studies learning students are less active, teachers plays a major role in teaching .

Furthermore, from the results of interviews conducted by researchers to the second grade teacher of SD Negeri Tropodo 2, students are known to have difficulty in remembering and understanding the material taught. The teacher has explained and explained but the students still do not understand the material so the teacher feels difficult when doing the learning. This can be seen from the learning outcomes of students, especially on the material position and role of family members. In addition to the problem of less motivated and less active students and teacher-centered learning. second problem Odd simester learning outcomes in the 2018/2019 school year, where students' social studies learning outcomes are still under the KKM, it is known from 25 students only 5 children who get 70 or above or while 12 other students get less scores from KKM or below 70 or the remaining 8 students get a score of less than 60 or when there are questions from the teacher regarding this material many who cannot answer correctly must be reminded by the previous explanation

One effort to overcome problems in learning, teachers must be able to design learning models that are meaningful to students. For this reason, teachers must be creative in designing learning models that allow students to participate, be active and creative about the material being taught, for example cooperative learning models (Susanto, 2013: 93). The cooperative learning model prioritizes collaboration in solving problems to apply knowledge and skills in order to achieve learning goals, all models are characterized by the structure of tasks, structure of goals, and structure of rewards (Daryanto and Rahardjo, 2012: 241). One innovative and interestinglearning model is thelearning model cooperativeScramble cooperative. According to Vita Septiana (2011: 9), Scramble is a learning model that can train students' creative power by arranging words, sentences, or discourses that are randomly arranged in a new arrangement that is meaningful and perhaps better than the original. This learning model allows students to learn while playing. Students can be creative at the same time can learn and think, learn things casually and do not make students become bored in the learning process so that students will be more active in the learning process

This is a result of the teacher's pattern in the conventional learning process and has not given students the opportunity to convey the idea, so the learning is still monotonous and dominated by teachers. Only give correct and wrong opinions to students. in completing the IPS question. The success of students in social studies learning so far still looks very lacking, it is this factor that encourages researchers to make improvements in the learning process which so far still looks lacking.

\section{Cooperative Learning Model Scramble}

Learning is an activity to gain knowledge and change mindset and behavior as a result of experience and practice. Slameto (2003: 2) suggests learning is a business process carried out by someone to obtain a change in new behavior as a whole, as a result of his own experience in interaction with his environment. Dimyati and Mujiono (2006: 18) learning is a complex internal process, which is involved in internal process which include affective elements, in the affective dimension related to attitudes, values, appreciation, and adjustment of social feelings. Furthermore Sagala (2008: 18)

Djamarah and Zain (2010: 28) states that learning is a process of changing behavior thanks to experience and practice. This means that the purpose of the activity is a change in behavior, knowledge, skills and attitudes even covering all aspects of the organism or person. Learning is a deliberate process and aims for students to get learning outcomes. In this activity learning occurs because of the interaction of students, and teachers.

Sudjana (2004: 28) Learning can be interpreted as any systematic and deliberate effort to createinteraction educational between two parties, namely between students (learning citizens) and educators (learning resources) who conduct learning activities. While according to Hamalik (2004: 77) states in the system approach, learning is a unity of the components of learning that cannot be separated from one another, because each other supports each other. These components can support the quality of learning. Learning as a system, meaning that a whole of the components that interact and interrelate with each other and with the whole itself to achieve the learning objectives that have been set before.

According to Johnson in cooperative learning is a model that prioritizes cooperation, namely cooperation between students in groups to achieve learning goals (Ismail, 2002: 12 ) in student learning divided into small groups and 
directed to study the material that has been determined, learning activities are mostly student-centered, students discuss to solve problems. The purpose of forming cooperative groups is to provide opportunities for students to be actively involved in the thinking process in teaching and learning activities. Thecooperative learning model srcamble is learning by using the question cards provided in accordance with the questions and matched with the answer cards that are done (Fadmawati, 2009) According to Hesti Damayanti (2019: 3-4) , Scramble is a model of learning carried out in groups requiring collaboration in work on the problem exercise as an emphasis with critical thinking so that solving the problem can be easily searched.

Learning Theory UnderlyingLearning Model Scramble Cooperative with Media Figure Suprijono (2017) states that the cooperative learning model has changed from Piaget's cognitive constructivism theory to Vygotsky's social constructivism. It is about understanding concepts from individuals to groups, social interactions, and socio-cultural activities. Piaget's constructivist theory is that students build knowledge using transformation, construction, organization, and prior reorganization of knowledge or information. Referring to Piaget's constructivist theory, the division learning model of student achievement is very suitable to be applied in the concrete operational stage. Effective strategies that can be used in

the concrete operational phase are: (1) students are involved in operational tasks such as compiling and sorting; (2) students practice organizing and grouping; (3) students make conclusions (Santrock, 2014). In addition, the syntax corresponds to the student achievement division learning model, which involves the presentation of classes, groups, quizzes, individual progress scores, and group awards (Slavin, 2005). The syntax of class presentations provides real examples or situations according to the concrete operational stage (Santrock, 2014). When students complete worksheets students and students practice compiling, grouping, and drawing conclusions.

The concrete operational phase are: (1) students are involved in operational tasks such as compiling and sorting; (2) students practice organizing and grouping; (3) students make conclusions (Santrock, 2014). In addition, the syntax corresponds to the student achievement division learning model, which involves the presentation of classes, groups, quizzes, individual progress scores, and group awards (Slavin, 2005). The syntax of class presentations provides real examples or situations according to the concrete operational stage (Santrock, 2014). When students complete worksheets students and students practice compiling, grouping, and drawing conclusions.

This is similar to Kim's opinion (2018) in his journal stating that the student achievement division learning model uses Vygotsky's constructivism learning theory. Suprijono (2017) states that Vygotsky's theory supports cooperative learning models found in the learning process through interactive dialogue and social interaction learning models. .

\section{Motivation and Learning Outcomes}

Motivation according to Schunk (in Eggen and Kauchak, 2012: 6) is a process of premature activities directed at achieving goals. Furthermore, according to Prawiro (2012: 320) motivation is an encouragement or effort in increasing activities to achieve certain goals. Motivation is defined as a series of businesses so that certain conditions are available, so that the desire arises to do something for someone. If you don't like it, it wil eliminate or avoid that feeling. (Uno, 2012: 75) Nawawi in Susanto (2013: 5) learning outcomes can be interpreted as the level of success of students in understanding the subject matter of the school which is stated by the assessment obtained from the test results in the form of scores. About certain subject matter. The abilities possessed by students after receiving learning experiences

outcomes, Sudjana, (2010: 10). States that learning outcomes are abilities possessed by students after getting taught, changing behavior is the essence of learning outcomes

\section{METHODS}

This study is an experimental study that aims to discern the effect of using scramble cooperative learning models by using media images to improve student motivation and learning outcomes in elementary schools, this study consisted of class $2 \mathrm{~A}$ as the experimental class and class $2 \mathrm{~B}$ as the control class held at Tropodo 2 Elementary School, Waru District, Sidoarjo Regency. This research was conducted in the second semester of the 2018/2019 academic year. This research study uses a quantitative approach whose implementation consists of three stages, namely: preparation stage, date of implementation, and data analysis. Data collection techniques in this study are by means of tests to find out the results of learning and observation. Observation is one of the data collection techniques that uses observations on research objects, where the implementation can be done directly (direct observation without tools) or indirectly (using tool intermediaries) Riyanto (2007 p. 83). Observations in this study used instruments. The observation instrument was conducted to find data about learning motivation in the learning process. Data analysis techniques used include normality test, homogeneity test, and test independent sample $t$-test

Pretest-PosttestControl Group Design

$\begin{array}{llcc}\text { Group } & \text { pretest } & \begin{array}{c}\text { Treatment } \\ \text { (Treatment of) }\end{array} & \text { Posttest } \\ \text { Experimen } & 01 & \mathrm{X} 1 & 02 \\ \text { Control } & 03 & \mathrm{X} 2 & 04\end{array}$

\section{Description:}

$\mathrm{O}_{1}=$ the results of pretest the experimental class

$\mathrm{O}_{2}=$ the results of the posttest experimental class 


$$
\begin{aligned}
\mathrm{O}_{3} & =\text { the results of pretest the control class } \\
\mathrm{O}_{4} & =\text { the result of posttest control class } \\
\mathrm{X}_{1} & =\text { class treatment usinglearning model scramble cooperative } \\
& \text { media-assistedimage }
\end{aligned}
$$

$\mathrm{X}_{2}=$ class treatment usinglearning model cooperative scramble without media image

\section{RESULTS AND DISCUSSION.}

Based on the results of the expert validation, the learning design consisting of syllabus, lesson plans, student worksheets, and observation sheets of student learning motivation which are forms of assessment design in good categorization, is quite valid, and feasible to use. Observations were made during group discussions and class presentations. Observation of student motivation is an observation of perseverance, seriousness, effort to obtain good grades. Students who succeed in this model, if they have applied the motivation indicators are stated in the good category. The following is an observation of the results of student motivation and learning outcomes in the experimental and control classes. Data analysisthis study techniques inData analysis techniques used normality test, homogeneity test, and independent sample t-test,value gainnormalized motivationalclass

Normality test

Variables Class significant Taraf Description

1. Motivation Control $0.115 \quad 0.05 \quad$ Normal

2. Motivation Experiment0.174 $0.05 \quad$ Normal

3. Learning

Outcomes
(pretest) Control $0.124 \quad 0: 05$ Normal

4. Learning

Outcomes

(posttest) Controls $0.141 \quad 0: 05 \quad$ Normal

5. Learning

\section{Outcomes}

(pretest) Experiment $0.149 \quad 0.05$ Normal

6. Lear ning

Outcomes

(posttest) Experimen $0.192 \quad 0.05$ Normal

The value of gain normalized motivationexperimental class 0.174 and control class 0.115 values gain normalized of students' learning outcomes experimental class 0.192 . and control class 0.141 So it can be stated that all variables in table 4.19 are normally distributed.

Table 1. of Test of Homogeneity of Variances

\section{Levene Statistic df1 df2Sig}

$\begin{array}{lcccc}\text { Motivation } & 2,230 & 1 & 48 & , 142 \\ \text { Pretests } & , 021 & 1 & 48 & , 886 \\ \text { Posttes } & , 008 & 1 & 48 & , 929\end{array}$

From the table above is homogeneity test data using a significance level of 0.05 or $5 \%$. If the significance is $<0.05$, the data group variance is not homogeneous, and if the significance is $>0.05$, the data group variant is homogeneous. In the learning motivation variable, the significance value is $0.142>0.05$, so the variable is homogeneous, in the learning outcome variable (pretest) obtained a significance value of $0.886>0.05$, it can be said that the variable is homogeneous. In the variable learning outcomes (posttest) obtained a significance value of $0.929>$ 0.05 , it can be said that the variable is homogeneous. From these three variables it can be concluded that the data is homogeneous or has met the basic assumptions of homogeneity.

The results of the analysis with the Independent Sample T-test on motivation obtained tvaluecount of 7.845 , the value of table at (df.48) and a significant level of 0.05 of 1,677 , if a comparison is made then $t_{\text {count }}<t_{\text {table }}$ with the results of sig. 2 tailed at 0,000 $<0,05$ and said to accept Ho which means that there is a significant difference. Which means there are differences in student learning motivation between the control class and the experimental class. At the pretest, the value of $t_{\text {count is }} 0.471$. The value of $t_{\text {table }}$ at (df.62) and the real level of 0.05 is 1,677, if a comparison is made then $t_{\text {count }}<t_{\text {table }}$ with the results of sig. 2 tailed $0.640>$ 0.05 and said to accept Ho which means that there is no significant difference. Which means there is no difference in student learning outcomes between the control class and the experimental class at the time of the pretest. While in the Posttest, the value of tarithmetic was 5.254. The value of

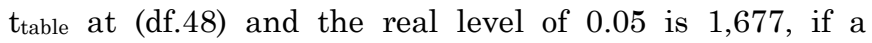
comparison is made The results of the analysis with the Independent Sample T-test on motivation obtained tvalue $_{\text {count }}$ of 7.845 , the value of table at (df.48) and a significant level of 0.05 of 1,677 , if a comparison is made then $t_{\text {count }}<t_{\text {table }}$ with the results of sig. 2 tailed at 0,000 $<0,05$ and said to accept Ho which means that there is a significant difference. Which means there are differences in student learning motivation between the control class and the experimental class. At the pretest, the value of $t_{\text {count is }}$ 0.471 . The value of $t_{\text {table }}$ at (df.62) and the real level of 0.05 is 1,677 , if a comparison is made then $t_{\text {count }}<t_{\text {table }}$ with the results of sig. 2 tailed $0.640>0.05$ and said to accept Ho which means that there is no significant difference. Which means there is no difference in student learning outcomes between the control class and the experimental class at the time of the pretest. While in the Posttest, the value of

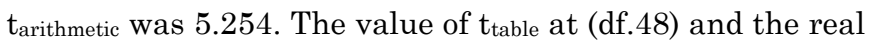
level of 0.05 is 1,677 , if a comparison is made then $t_{\text {count }}>$ table with the results of sig. 2 tailed at 0,000<0,05 and said to receive $\mathrm{Ha}$ which means that there are significant differences. Which means that there are differences in student learning outcomes between the control class and 
the experimental class at the posttest.

\section{DISCUSSION}

Based on the data analysis techniques obtained from the data from the normality test the normality test for motivation to learn motivation in the control class obtained a significant value of $0.115>0.05$. The motivation variable in the experimental class obtained a significant value of $0.174>0.05$. Then it can be concluded that the data is normally distributed. the results of the analysis ofnormality the prettesvariable test in the control class obtained a significance value of $0.124>0.05$ on the posttest learning outcomes of control class students obtained a significance value of $0.141>0.05$, the variable learning outcomes pretest students in the experimental class obtained a significance value of $0.149>0.05$, on the posttest learning outcomes of students in the experimental class obtained a significance value of $0.192>0.05$. So that it can be stated that all variables are normally distributed.

Based on the results of data analysis using SPSS rock shows that the T-test results obtained avalue significantfor learning motivation of $0,000<0,05$ and said to accept Ho which means that there are significant differences. Which means there are differences in student learning motivation between the control class and the experimental class. At the pretest, a value of $0.640>0.05$ was obtained and said to be accepted Ho, which means that there were no significant differences. Which means there is no difference in student learning outcomes between the control class and the experimental class at the time of the pretest. While the Posttest obtained a va

During learning usinglearning models cooperative scramble. The $\mathrm{T}$ test in this study shows that the use oflearning models scramble cooperative with image media can influence and simultaneously influence motivation and learning outcomeslue of $0,000<0,05$ and said to receive $\mathrm{Ha}$ which means that there are significant differences. Which means that there are differences in student learning outcomes between the control class and the experimental class at the posttest

\section{CONCLUSION}

Based on the results of research and data analysis, several conclusions of the research results can be stated as follows:

1. Is there a significant effect of the application of thelearning model cooperative scramble with picture media on student learning motivation material social studies subjects position and role of class 2 family members SDN Tropodo 2 This can be proved by the Independent Sample T-test on motivation obtained tvalue $_{\text {count }}$ of $7.845, t_{\text {table value }}$ at (df. 48) and a significant level of 0.05 of 1,677 , if a comparison is made then $t_{\text {count }}$

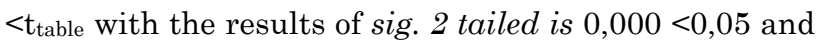
said to accept Ho which means that there is a significant difference, meaning that there are differences in student learning motivation between the control class and experimental class
2. Is there a significant effect Application of thelearning model scramble cooperative with image media on student achievement in social studies subjects material position and role of class 2 SDN Tropodo 2 family members at Pretest obtained tvalue count of 0.471 . The value of table at (df.62) and the real level of 0.05 is 1,677 , if a comparison is made then $t_{\text {count }}<t_{\text {table }}$ with the results of sig. 2 tailed $0.640>0.05$ and said to accept Ho which means that there is no significant difference. Which means there is no difference in student learning outcomes between the control class and the experimental class at the time of the pretest. While in the Posttest, the value of tarithmetic was 5.254. The value of table at (df.48) and the real level of 0.05 is 1,677, if a comparison is made then $t_{\text {count }}>t_{\text {table }}$ with the results of sig. 2 tailed at $0,000<0,05$ and said to accept Ha which means that there are significant differences, meaning that there are differences in student learning outcomes between the control class and the experimental class at the time of posttest

\section{REFERENCES}

Daryanto and Raharjo. 2011.Research Classroom Actionand School Action Research along with Examples. Yogyakarta: Gava Media.

Djamarah, Syaiful Bahri and Aswan Zain. 2010. Teaching and Learning Strategies. Jakarta: Rineka Cipta

Hidayati. 2004. Social Sciences Education in Elementary Schools. Raja Grafindo Persada: Yogyakarta FKIP-UT Team (2013). Strengthening Professional Capabilities. South Tangerang:Open University

Hamalik, Oemar. 2003. Teaching and Learning Process. Jakarta: Rineka Cipta.

Hamalik, Oemar. 2004. Teaching and Learning Process. Jakarta: Rineka Cipta.

Riyanto, Yatim. 2007. Educational Research Methods. Qualitative and quantitative. Surabaya: Unesa University Press

Sagala, Syaiful. 2008.Concept and Meaning of Learning. Bandung: Alfabeta

Slameto. 2003. Learning and Learning. Jakarta: Rineka Cipta

Sudjana, Nana. 2004. Basics of the Teaching and Learning Process. Bandung: Sinar Baru Algensido Offset.

Sudjana, Nana. 2010. Evaluation of Teaching and Learning Process Results.Bandung: Youth, Rosdakarya

Susanto, Ahmad. 2013. Theory of Learning and Learning in Primary Schools. Jakarta: Kencana Anitah, Sri. 2008. Learning Media. Surakarta: SurakartaTeacher Certification partner

Uno, Hamzah B. (2012). Theory of Motivation and Measurement of Analysis in the Field of Education. Jakarta: Bumi Aksara Tirtarahardja, Umar, Sulo. 2008. Introduction to Education. Jakarta:Rineka Cipta

Atik Artiningsih, Postgraduate Student, Surabaya State University, Indonesia, paramita.17070855071@mhs.unesa.ac.id

Yatim Riyanto, Professor, Faculty of Science Education, University 